\title{
Non-genetic factors affecting pre-weaning growth and morphometric traits in Assam Hill goat
}

\author{
L. Sarma ${ }^{1}$, N. Nahardeka², R. N. Goswami ${ }^{1}$, A. Aziz ${ }^{1}$, G. Zaman ${ }^{1}$, A. Das ${ }^{1}$ and F. Akhtar ${ }^{2}$
}

1. Department of Animal Genetics and Breeding, College of Veterinary Sciences, Assam Agricultural University, Guwahati, Assam, India; 2. Goat Research Station, Assam Agricultural University, Burnihat -793101, Assam, India.

Corresponding author: L. Sarma, e-mail: lopa.upa07@gmail.com

Co-authors: NN: nabanahardeka@gmail.com, RNG: dean.fvsc.aau@gmail.com, AA: azizabdul54@gmail.com, GZ: gzaman60@gmail.com, AD: arpana_agb@yahoo.co.in,FA: drfarzinakhtar@gmail.com Received: 27-02-2019, Accepted: 09-07-2019, Published online: 25-08-2019

doi: 10.14202/vetworld.2019.1327-1331 How to cite this article: Sarma L, Nahardeka N, Goswami RN, Aziz A, Zaman G, Das A, Akhtar F (2019) Non-genetic factors affecting pre-weaning growth and morphometric traits in Assam Hill goat, Veterinary World, 12(8): 1327-1331.

\begin{abstract}
Aim: This study aimed to determine the genetic and non-genetic factors affecting pre-weaning body weight (BW) and morphometry in Assam Hill goat along with the genetic parameters.

Materials and Methods: The detailed information in respect of BW and body measurements of 960 animals at birth and 3 months of age belonging to three different populations of Assam Hill goat maintained at field units, namely, Batabari, Nahira, and Tetelia under "All India Coordinated Research Project on Goat Improvement" were utilized in the present study. The data were analyzed using least squares technique.

Results: The least squares means for BW, height at withers (HW), heart girth (HG), and body length (BL) were $1.166 \pm 0.008 \mathrm{~kg}, 26.198 \pm 0.070 \mathrm{~cm}, 26.695 \pm 0.096 \mathrm{~cm}$, and $29.482 \pm 0.119 \mathrm{~cm}$ at birth and $4.590 \pm 0.083 \mathrm{~kg}, 36.850 \pm 0.105 \mathrm{~cm}$, $40.741 \pm 0.115 \mathrm{~cm}$, and $39.703 \pm 0.108 \mathrm{~cm}$ at 3 months of age, respectively. Location had a significant effect on BW, HW, and $\mathrm{BL}$ at both birth and 3 months and on HG at 3 months of age. Season of birth exerted significant effect only on BL at birth, whereas the significant effect of sex was observed on HG and BL at 3 months of age. The heritability estimates for BW and body measurements were moderate indicating the scope of selection. The phenotypic and genetic correlations among BWs and body measurements at birth and 3 months of age were positive in direction and high in magnitude.
\end{abstract}

Conclusion: On the basis of the present findings, it could be concluded that the weaning weight of kids can be considered for the selection of parent stock to increase productivity and eventually the economic efficiency. Further, animals with higher body measurements at initial phases of growth will perform better with respect to even BW at later stages of growth.

Keywords: Assam Hill goat, genetic parameters, morphometric traits, non-genetic factors, pre-weaning growth.

\section{Introduction}

Goat substantially contributes to the rural economy and provides a livelihood to the poor sections of the society. India possesses the second largest goat population in the world with 135.17 million goats $(26.40 \%$ of the country's total livestock) which corresponds to $15.68 \%$ of total goat population in the world [1]. The goat population of Assam is 6.169 million, contributing $4.56 \%$ of total goat population of India [1]. The Assam Hill goat is a newly registered breed distributed throughout the state of Assam possessing good quality meat and high adaptability characteristics to local high humid agro-climatic condition. Almost the entire population of Northeastern region of India is non-vegetarian and chevon is the meat of choice having no religious taboo. The chevon production in Assam in the year 2012-2013 was 11,000 tonnes which were

Copyright: Sarma, et al. Open Access. This article is distributed under the terms of the Creative Commons Attribution 4.0 International License (http://creativecommons.org/licenses/by/4.0/), which permits unrestricted use, distribution, and reproduction in any medium, provided you give appropriate credit to the original author(s) and the source, provide a link to the Creative Commons license, and indicate if changes were made. The Creative Commons Public Domain Dedication waiver (http://creativecommons.org/ publicdomain/zero/1.0/) applies to the data made available in this article, unless otherwise stated.
$20 \%$ of the total meat produced in the state [1]. The gap between demand and production of meat could be bridged by augmenting the growth performance and reproductive efficiency of the animals.

Birth weight is an important parameter in meat-producing animals due to its strong correlation with growth rate and adult size as well as with the viability of newborn animals, while weaning weight has a high relative economic importance to the farmers [2]. Evaluation of early growth and morphometric traits indicates the growth trends which enable more accurate assessment of growth potentials; better understanding of the impact of genetic and environmental factors on growth; more accurate prediction of mature growth and linear body values before attainment of maturity; and early selection, reduction of generation interval, and rapid genetic progress [3]. In meat-producing animals, external body measurements could be a reliable indicator of its future performance with respect to live body weights (BWs), if and only if a correlation has been identified among these traits of interest [4]. To formulate efficient breeding plans and selection strategies, knowledge of genetic parameters (heritability) among various traits is essential $[5,6]$. 
This study aimed to determine the genetic and non-genetic factors affecting pre-weaning BWs and morphometry in Assam Hill goat along with the genetic parameters.

\section{Materials and Methods}

\section{Ethical approval}

The present work has been approved by the Institutional Animal Ethics Committee of Assam Agricultural University, vide Approval No. 770/ ac/CPCSEA/FVSc/AAU/IAEC/15-16/285 dated 10.04. 2015.

\section{Location and data collection}

The animals used in this study were reared by the farmers belonging to the field units under "All India Coordinated Research Project on Goat Improvement," Goat Research Station, Assam Agricultural University, Burnihat. The location lies between $90.48^{\circ}$ and $92.22^{\circ}$ (East) longitude and $20.09^{\circ}$ and $26.95^{\circ}$ (North) latitude. The data pertaining to 960 animals were utilized in the present investigation. Measurements of four morphological characters, namely, BW, height at withers (HW), heart girth (HG), and body length (BL) were recorded at birth and 3 months of age according to measurement regions [7]. Measuring tapes were used to record the length and HG in centimeter, while the heights were measured using graduated stick. The BWs were measured using spring balance of $50 \mathrm{~kg}$ capacity in the morning hours. The birth weights of the kids were recorded within $12 \mathrm{~h}$ of birth. The data were classified into three locations, namely, Batabari $\left(\mathrm{L}_{1}\right)$, Nahira $\left(L_{2}\right)$, and Tetelia $\left(L_{3}\right)$; four seasons of birth, namely, pre-monsoon, i.e., March-May $\left(\mathrm{S}_{1}\right)$, monsoon i.e., JuneSeptember $\left(\mathrm{S}_{2}\right)$, post-monsoon, i.e., NovemberDecember $\left(\mathrm{S}_{3}\right)$, and winter, i.e., December-February $\left(\mathrm{S}_{4}\right)$; and two sexes as male and female.

\section{Management practices}

The goat sheds were made of locally available materials, i.e., bamboo, wood, thatches, etc. The slotted floors of the houses were raised by about $3 \mathrm{ft}$. The walls of the shed were made of bamboo and covered up to three-fourth of the total height of the wall and rest of the portions were kept open for ventilation. The animals were kept under semi-intensive management system. Selective breeding was practiced where the breeding does were mated with superior bucks supplied under the project. All the male kids except those kept for breeding purpose were castrated before 3 months of age. The animals were immunized regularly against enterotoxemia, peste des petits ruminants, and goat pox. Regular deworming was practiced in all the field units under study.

\section{Statistical methods}

The data were analyzed using least squares means (LSM) as described by Harvey [8]. The statistical model used to analyze the data was $\mathrm{Y}_{\mathrm{ijko}}=\mu+\mathrm{L}_{\mathrm{i}}+\mathrm{M}_{\mathrm{j}}+\mathrm{S}_{\mathrm{k}}+\mathrm{e}_{\mathrm{ijk}}$, where $Y_{i j k o}$ is the value of the $\mathrm{O}^{\text {th }}$ animal in the $(\mathrm{ijk})^{\text {th }}$ subclass, $\mu$ is the overall population mean, $L_{i}$ is the

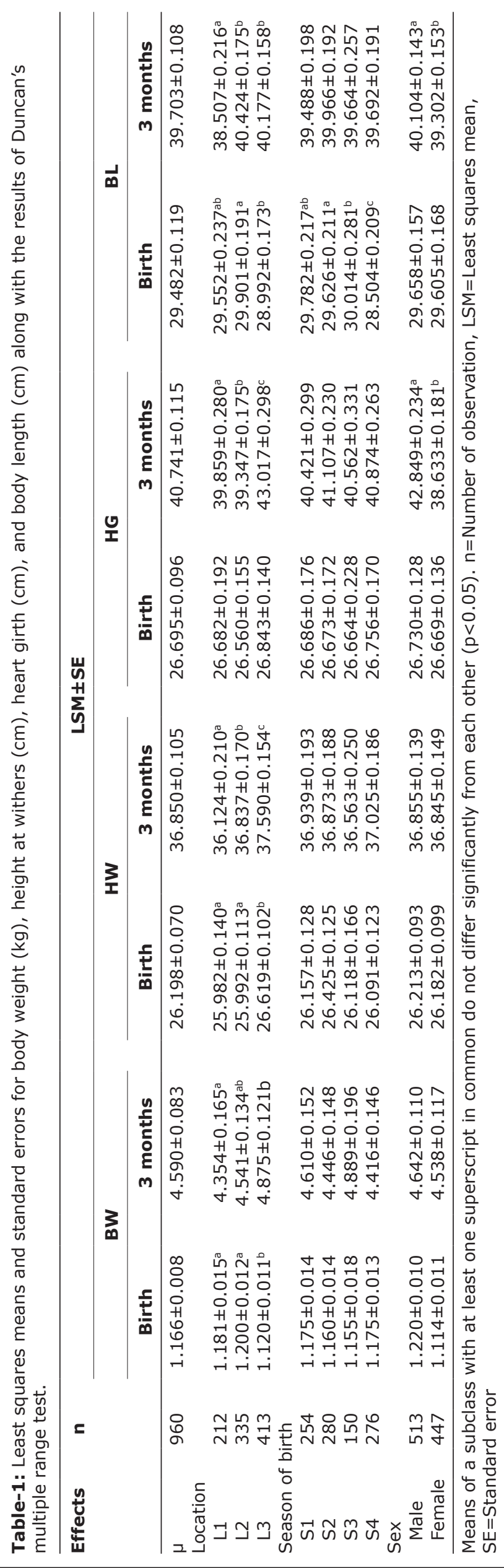

Veterinary World, EISSN: 2231-0916 
Table-2: Least squares analyses of variance for body weight, height at withers, heart girth, and body length.

\begin{tabular}{|c|c|c|c|c|c|c|c|c|c|}
\hline \multirow{3}{*}{$\begin{array}{l}\text { Sources of } \\
\text { variation }\end{array}$} & \multirow[t]{3}{*}{ df } & \multicolumn{8}{|c|}{ MS } \\
\hline & & \multicolumn{2}{|c|}{ BW } & \multicolumn{2}{|c|}{ HW } & \multicolumn{2}{|r|}{ HG } & \multicolumn{2}{|c|}{ BL } \\
\hline & & Birth & 3 months & Birth & 3 months & Birth & 3 months & Birth & 3 months \\
\hline Location & 2 & $0.647 *$ & $21.309 *$ & $14.357 *$ & 155.234** & 7.300 & $4556.688 * *$ & $36.570 *$ & $266.945^{* *}$ \\
\hline Season of birth & 3 & 0.022 & 8.683 & 6.124 & 7.217 & 0.431 & 4417.850 & $31.397 *$ & 10.212 \\
\hline Sex & 1 & 0.032 & 2.609 & 0.223 & 0.024 & 0.618 & $6549.005 * *$ & 14.607 & $38.126 *$ \\
\hline Error & 953 & 0.157 & 5.734 & 4.102 & 9.300 & 7.757 & 986.296 & 11.759 & 9.801 \\
\hline
\end{tabular}

$*_{p}<0.05, * *_{p}<0.01$. BW=Body weight, $\mathrm{HW}=$ Height at withers, $\mathrm{HG}=$ Heart girth, $\mathrm{BL}=$ Body length

effect of $i^{\text {th }}$ location $(i=1,2,3), M_{j}$ is the effect of $j^{\text {th }}$ season of birth $(j=1,2,3,4), S_{k}$ is the effect of the sex of the kid $(\mathrm{k}=1,2)$, and $\mathrm{e}_{\mathrm{ijko}}$ is the random error associated with $\mathrm{Y}_{\mathrm{ijko}}$ assumed to be $\operatorname{NID}\left(0, \sigma_{\mathrm{e}}^{2}\right)$. Duncan's multiple range test (DMRT) was done to make pairwise comparison among the means wherever significant differences exist.

The estimates of heritability $\left(h^{2}\right)$, phenotypic $\left(r_{p}\right)$, and genetic $\left(\mathrm{r}_{\mathrm{G}}\right)$ correlations were calculated from the sire component of variance and covariance. The statistical model used to estimate the genetic parameters was $Y_{i j}=\mu+S_{i}+e_{i j}$, where $Y_{i j}$ is the observed value of $j^{\text {th }}$ progeny on $\mathrm{i}^{\text {th }}$ sire, $\mu$ is the overall population mean, $\mathrm{S}_{\mathrm{i}}$ is the effect of $\mathrm{i}^{\text {th }}$ sire common to all its progeny $(i=1,2,3 \ldots)$, and $e_{i j}$ is the random error component assumed to be $\operatorname{NID}\left(0, \sigma_{\mathrm{e}}^{2}\right)$. Standard errors (SEs) of heritability, phenotypic, and genetic correlation were estimated using the standard statistical methods.

\section{Results and Discussion}

The estimates of LSM and SE for BW, HW, HG, and $\mathrm{BL}$ at birth and 3 months of age along with the results of DMRT are presented in Table-1, and least squares analyses of variance showing the effect of different factors on the traits are presented in Table-2.

BW

The overall $\mathrm{LSM} \pm \mathrm{SE}$ for birth weight were found to be $1.166 \pm 0.008 \mathrm{~kg}$ in the present study (Table-1) which is in conformity with the finding of Otuma and Onu [9] in Nigerian crossbred goats; while, the reports of Mia et al. [10] in Black Bengal goat support the mean value for weaning weight in the present study which was found to be $4.590 \pm 0.083 \mathrm{~kg}$ (Table-1). However, the present finding is higher than the finding of Miah et al. [11] for birth weight and the finding of Singh and Singh [12] for weaning weight in Black Bengal goats. In contrast, Syahirah et al. [13] reported higher values for both the traits in Boer kids.

\section{Effect of location}

Location had a significant effect on both birth and weaning weight (Table-2). Kids born at Nahira unit exhibited higher birth weights as compared to Batabari and Tetelia unit. This might be due to better management practices adopted by the farmers of Nahira. Weaning weight of kids of Tetelia unit significantly differed from the kids of Batabari. This could
Table-3: Estimates of heritability $\left(h^{2}\right)$, phenotypic $\left(r_{p}\right)$, and genetic $\left(r_{G}\right)$ correlation between birth and weaning weight.

\begin{tabular}{lcc}
\hline $\mathbf{r}_{\mathbf{G}}$ & \multicolumn{2}{c}{$\mathbf{r}_{\mathbf{P}}$} \\
\cline { 2 - 3 } & Birth & 3 months \\
\hline Birth & $0.2611 \pm 0.117$ & $0.6455 \pm 0.019$ \\
3 months & $0.4231 \pm 0.256$ & $0.1169 \pm 0.067$ \\
\hline
\end{tabular}

N.B. The elements of the diagonal are the estimates of heritability, above the diagonal is the phenotypic correlation, and below the diagonal is the genetic correlation

be justified by proper postnatal care and management by the farmers of Tetelia unit along with availability of mother's milk to the unweaned kids.

\section{Effect of season of birth}

Non-significant effect of season of birth was observed on both the traits (Table-2), which is in agreement with the observations of Faruque et al. [14] in Black Bengal goats for birth weight and Bedhane et al. [15] in Arsi-Bale goats for weaning weight. However, a significant effect of season of birth on both the traits was reported by Mahal et al. [16] in Black Bengal goats.

\section{Effect of sex}

Analyses of variance revealed that birth and weaning weight were not significantly affected by sex of kids though the weights of male kids were higher than the females (Table-2). Similar observations were obtained by Mia et al. [10] in Black Bengal goats. However, a significant effect of sex of kid was reported by Bedhane et al. [15] in Arsi-Bale goats for both the traits. The increase in BW of male goats might be attributed to the early activation of male gonads than the females. Male sex hormone testosterone responsible for the anabolic effect could have caused the faster growth in male animals.

\section{HW, HG, and BL}

The overall $\mathrm{LSM} \pm \mathrm{SE}$ for $\mathrm{HW}, \mathrm{HG}$, and $\mathrm{BL}$ were $26.198 \pm 0.070 \mathrm{~cm}, 26.695 \pm 0.096 \mathrm{~cm}$, and $29.482 \pm 0.119 \mathrm{~cm}$ at birth and $36.850 \pm 0.105 \mathrm{~cm}$, $40.741 \pm 0.115 \mathrm{~cm}$, and $39.703 \pm 0.108 \mathrm{~cm}$ at 3 months of age, respectively (Table-1). These findings are in accordance with the findings of Pan et al. [17] in Black Bengal goats. However, much higher values were recorded in Sirohi goats for all the traits by Dudhe et al. [18]. 
Table-4: Estimates of heritability $\left(h^{2}\right)$, phenotypic $\left(r_{p}\right)$, and genetic $\left(r_{G}\right)$ correlation between body weight and body measurements at birth and 3 months of age.

\begin{tabular}{lcccc}
\hline $\mathbf{r}_{\mathbf{G}}$ & \multicolumn{3}{c}{$\mathbf{r}_{\mathbf{P}}$} \\
\cline { 2 - 5 } & $\mathbf{B W}$ & $\mathbf{H W}$ & $\mathbf{H G}$ & $\mathbf{B L}$ \\
\hline Birth & & & & \\
BW & $0.2611 \pm 0.117$ & $0.4492 \pm 0.032$ & $0.4306 \pm 0.026$ & $0.4357 \pm 0.032$ \\
HW & $0.4430 \pm 0.302$ & $0.1244 \pm 0.070$ & $0.6334 \pm 0.017$ & $0.7620 \pm 0.032$ \\
HG & $0.5188 \pm 0.203$ & $0.2173 \pm 0.341$ & $0.2444 \pm 0.112$ & $0.4772 \pm 0.032$ \\
BL & $0.4051 \pm 0.270$ & $0.4821 \pm 0.351$ & $0.3588 \pm 0.297$ & $0.2750 \pm 0.122$ \\
months & $0.1169 \pm 0.067$ & $0.6682 \pm 0.032$ & $0.4991 \pm 0.032$ & $0.4847 \pm 0.032$ \\
BW & $0.4247 \pm 0.336$ & $0.4406 \pm 0.174$ & $0.5640 \pm 0.032$ & $0.6835 \pm 0.032$ \\
HW & $0.4426 \pm 0.364$ & $0.3644 \pm 0.278$ & $0.1567 \pm 0.081$ & $0.5001 \pm 0.031$ \\
HG & $0.3577 \pm 0.335$ & $0.4381 \pm 0.291$ & $0.6280 \pm 0.338$ & $0.2643 \pm 0.118$ \\
BL & & & & \\
\hline
\end{tabular}

N.B. The elements of the diagonal are the estimates of heritability, above the diagonal is the phenotypic correlations,

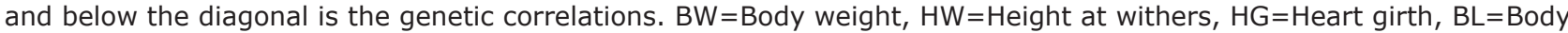
length

\section{Effect of location, season of birth, and sex of kids on morphometric traits}

Location affected HW and BL significantly at both the age groups, but $\mathrm{HG}$ at weaning age only (Table-2).

Non-significant effect of season of birth on HW and $\mathrm{HG}$ at both age groups was observed in the present investigation (Table-2). However, a significant effect on HG was observed by Dudhe et al. [18] in Sirohi goats. On the other hand, there was a significant effect of season of birth on BL at birth in the present investigation (Table-2). The mean BL was comparatively higher in goats born during post-monsoon season. The result is in accordance with the finding of Dudhe et al. [18] in Sirohi goats.

Although differences in HW at birth and weaning due to sex were not significant, the values of the LSM for male animals were higher than those for the females (Table-2). On the contrary, sex of kids exerted significant effects on $\mathrm{HG}$ and $\mathrm{BL}$ at weaning in the present study (Table-2) which is in the flow of the reports obtained by Dudhe et al. [18] in Sirohi goats. The values of HG were found to be higher in male goats than those of females. However, a non-significant effect was observed by Kharkar et al. [19] in Berari goats.

\section{Genetic parameters}

The estimates of genetic parameters, namely, heritability $\left(h^{2}\right)$, phenotypic correlation $\left(r_{p}\right)$, and genetic correlation $\left(\mathrm{r}_{\mathrm{G}}\right.$ ) along with the SE among BWs and body measurements at birth and 3 months of age are presented in Tables-3 and 4.

\section{Heritability}

The heritability estimates for birth and weaning weight under study were moderate (Table-3), which are in the line of the estimates of Kenneth et al. [20] and Kuthu et al. [5] in meat goats of the USA and Teddy goats, respectively. Moderate estimates indicated the scope for improvement of the traits through selection. However, lower estimates of heritability were obtained by Faruque et al. [14] in Black Bengal goats for birth weight and Bedhane et al. [15] in
Arsi-Bale goats for weaning weight. On the contrary, higher values than the present estimates were reported by Mia et al. [10] in Black Bengal goats for both the traits.

Similarly, moderate estimates of heritability were obtained for $\mathrm{HW}, \mathrm{HG}$, and $\mathrm{BL}$ at birth and weaning in the present study (Table-4) which also indicated scope of improvement by selection. However, Dudhe et al. [18] in Sirohi goats reported higher estimates of heritability for morphometric traits as compared to the present estimates.

\section{Phenotypic and genetic correlation}

The phenotypic and genetic correlations among pre-weaning BWs were found to be positive and high at both the age groups (Table-3). It has considerable significance in the selection program for BW since $\mathrm{BW}$ at one of these early ages is a good indication of $\mathrm{BW}$ at 12 months of age. These high correlations are of economic importance and suggest that the genetic factors are largely similar for these early and 12 months of age. These findings are in conformity with the findings of Mia et al. [10] in Black Bengal goats.

The phenotypic and genetic correlations among BWs and various body measurements were found to be positive and high at both the age groups (Table-4). This indicated that the linear body measurements could reliably play a predictive role for BW at any given age. BW appeared to be a function of these body measurements. This indicated the possibility of improving BW as a correlated response by exerting selection pressure on the body measurements. Dudhe et al. [18] in Sirohi goats reported positive and high phenotypic and genetic correlation among body measurements as obtained in the present study.

\section{Conclusion}

Weaning weight of kids can be considered for the selection of parent stock to increase productivity and eventually the economic efficiency. These results, therefore, provide an important perspective on the selection objectives of Assam Hill goats by considering different environmental factors. Since BW 
and body measurements are important parameters to describe growth, so selective breeding of Assam Hill goat based on these parameters needs to be given more emphasis for greater productivity.

\section{Authors' Contributions}

LS and NN designed the experiment and conducted the study; RNG, AA, and GZ analyzed and interpreted the data; and $\mathrm{AD}$ and FA revised the manuscript. All authors read and approved the final manuscript.

\section{Acknowledgments}

The authors acknowledge the support of staffs of AICRP on Goat Improvement, Goat Research Station, Burnihat, and Department of Animal Genetics and Breeding for providing the facilities as well as information for this study. The financial support for the study was provided by the AICRP on Goat Improvement, Goat Research Station, Burnihat vide grant No. 99/ DRV/751-4/2015-16/158 dated 25.02.2016.

\section{Competing Interests} interests.

The authors declare that they have no competing

\section{Publisher's Note}

Veterinary World remains neutral with regard to jurisdictional claims in published institutional affiliation.

\section{References}

1. Basic Animal Husbandry and Fisheries Statistics. (2014) Department of Animal Husbandry, Dairying and Fisheries. Ministry of Agriculture, Government of India.

2. Cilek, S. and Gotoh, T. (2015) Effects of dam age, lamb gender and singleton or twin status on body weight and chest measurements of Malya lambs in Middle Anatolia, Turkey. Fac. Agric. Kyushu Univ., 60(2): 371-375.

3. Akpa, G.N., Ambali, A.L. and Suleiman, I.O. (2013) Body conformation, testicular and semen characteristics as influenced by age, hair type and body condition of Red Sokoto goat. N. Y. Sci. J., 6(7): 44-58.

4. Tomar, A.K.S., Kumar, A., Mehta, B.S. and Jaishankar, J. (2001) Factors affecting early express body traits in Sirohi goats. Indian J. Anim. Sci., 71(3): 271-273.

5. Kuthu, Z.H., Javed, K., Babar, M.E., Sattar, A. and Abdullah, M. (2017) Estimation of genetic parameters for pre-weaning growth traits in teddy goats. J. Anim. Plant Sci., 27(5): 1408-1414.

6. Çilek, S. and Şahin, E.H. (2009) Estimation of some genetic parameters (heritability and repeatability) for milk yield in the Anatolian population of Holstein cows. Arch. Zootech., 12(1): 57-64.

7. Çilek, S. and Gotoh, T. (2014) Effects of dam age, lamb gender and singleton or twin status on body size of Malya lambs in middle Anatolia, Turkey. Fac. Agric. Kyushu Univ., 59(2): 313-320.

8. Harvey, W.R. (1990) User's Guide for LSMLMW. Mixed Model L.S Maximum Likelihood Computer Programme PC-Version 2. Ohio State University, Columbus, USA.

9. Otuma, M.O. and Onu, P.N. (2013) Genetic effects, relationships and heritability of some growth traits in Nigeria crossbred goats. Agric. Biol. J. North Am., 4(4): 388-392.

10. Mia, M.M., Khandoker, M.A.M., Husain, S.S., Faruque, M.O., Notter, D.R. and Haque,M.N. (2013) Genetic evaluation of growth traits of black Bengal goat. Iran. J. Appl. Anim. Sci., 3(4): 845-852.

11. Miah, G., Das, A., Bilkis, T., Momin, M.M., Uddin, M.A., Mohammad, M.A.A., Mahmud, S. and Miazi, O.F. (2016) Comparative study on productive and reproductive traits of black Bengal and jamnapari goats under semi-intensive condition. Sci. Res. J., 4(2): 1-6.

12. Singh, N.K. and Singh, D.K. (1998) Growth rate of black Bengal and its crosses with beetal under village conditions. Indian J. Anim. Sci., 68(9): 988-990.

13. Syahirah, M.Y., Mat, K.B., Rusli, N.D. and Hasnita, C.H. (2016) Preliminary study on birth weight and pre-weaning growth pattern in crossed Boer kids. J. Trop. Resour. Sustain. Sci., 4(1): 6-9.

14. Faruque, S., Chowdhury, S.A., Siddiquee, N.U. and Afroz, M.A. (2010) Performance and genetic parameters of economically important traits of black Bengal goat. $J$. Bangladesh Agric. Univ., 8(1): 67-78.

15. Bedhane, M., Haile, A., Dadi, H. and Alemu, T. (2013) Estimates of genetic and phenotypic parameters for growth traits in arsi-bale goat in Ethiopia. J. Anim. Sci. Adv., 3(9): 439-448.

16. Mahal, Z., Khandoker, M.A.M. and Haque, M.N. (2013) Effect of non genetic factors on productive traits of black Bengal goats. J. Bangladesh Agric. Univ., 11(1): 79-86.

17. Pan, S., Biswas, C.K., Majumdar, D., Sengupta, D., Patra, A., Ghosh, S. and Haldar, A. (2015) Influence of age, body weight, parity and morphometric traits on litter size in prolific black Bengal goats. J. Appl. Anim. Res., 43(1): 104-111.

18. Dudhe, S.D., Yadav, S.B., Nagda, S.R.K., Pannu, U. and Gahlot, G.C. (2015) Genetic and non-genetic factors affecting morphometry of sirohi goats. Vet. World, 8(11): 1356-1363.

19. Kharkar, K., Kuralkar, S.V. and Kuralkar, P. (2014) Growth, production and reproduction performance of berari goats in their native tract. Indian J. Small Rumin., 20(1): 12-15.

20. Kenneth, M.A., Frederick, B., Andrew, M., Amoris, B. and Amber, H. (2016) Estimation of Genetic Parameters for Birth to Weaning Traits in Meat Goat. Proceedings of the Meeting Animals and the Science: Big Solutions for Grand Challenges, July 19-23, Salt Lake City, UT. 